\title{
AZ ESG-MINŐ́SÍTÉS HATÁSA A VÁLLALATI KÖTVÉNYHOZAMOKRA
}

\author{
Kotró Balázs - Márkus Martin ${ }^{1}$
}

Jelen tanulmány azt vizsgálja, hogy a piac kockázatosabbnak értékeli-e az olyan vállalati kötvényeket, amelyeknek a kibocsátója alacsonyabb ESG (Environmental - Social - Governance) pontszámmal rendelkezik. A vizsgált populációba a Refinitiv vállalati hozamgörbéi kerültek, amelyeket hitelminősítés alapján tovább szegmentáltunk. Az ESG-faktor által hozzáadott kockázatot 5 éves időtávban mértük, 2015 és 2020 között. Ezen időtáv alatt kirajzolódott, hogy a Moody’s legjobb adósbesorolású vállalatainak a csoportjában a befektetők átlagosan 35 bázisponttal magasabb kockázati felárat várnak el a legalacsonyabb ESG-pontszámú vállalatoktól, mint a legmagasabb pontszámúaktól az Egyesült Államokban. A jelenség külön az E, S és G besorolás alapján is megfigyelhető. További trend, hogy a felelős működés hiánya okozta kockázati felár annál kisebb, minél kockázatosabb hitelminősítési kategórián belül vizsgálódunk.

Jel-kódok: G1, G11, G110, G120, Q5

Kulcsszavak: ESG-befektetések, ESG-kockázat, hozamgörbe, hozamfelár

\section{BEVEZETÉS}

A következő tanulmányban a felelös, zöld, fenntartható befektetések mérésére az utóbbi években a legáltalánosabbá vált ESG-faktorokat (környezeti, társadalmi, irányítási) használtuk (Amel-Zadeh-Serafeim, 2017). A részvényhozamok és a felelős befektetői magatartás közötti kapcsolat kutatása jelentős szakirodalommal rendelkezik. Gunnar és társai (2015) tanulmánya körülbelül 2200 egyedi kutatás eredményét összegezte a pénzügyi teljesítmény és az ESG kapcsolatáról, míg Orlitz és társai (2003) 52 tanulmány eredményeit összefoglalva próbáltak megalapozott következtetésekre jutni. A kutatások többsége arra a konklúzióra jut, hogy a befektetők figyelembe veszik tőkepiaci döntéseik során, hogy az adott kibocsátó mennyire hat pozitívan vagy negatívan a szüken és tágan értelmezett környezeté-

1 Kotró Balázs PhD-hallgató, Befektetések és Vállalati Pénzügy Tanszék, Budapesti Corvinus Egyetem. E-mail: balazsbence.kotro@uni-corvinus.hu.

Márkus Martin PhD-hallgató, Befektetések és Vállalati Pénzügy Tanszék, Budapesti Corvinus Egyetem. E-mail: martin.markus@uni-corvinus.hu. 
re, a társadalomra, illetve, hogy milyen vállalatvezetési gyakorlattal és kultúrával rendelkezik. Az Amundi Asset Management Research keretében Bennani és társai (2018) kutatása alapján a vizsgált portfóliók legjobb ESG-besorolású részvényeinek megvételével, illetve a legrosszabb besorolású részvényeinek eladásával 2014 és 2017 között 3,3\% többlethozamot lehetett realizálni a piaci portfólióhoz képest az amerikai piacon, míg hasonló időtávon, ugyanezt a stratégiát követve 6,6\% extra hozamot lehetett elérni az európai tőkepiacon. Egyes tanulmányok azonban nem találnak egyértelmü, hosszú távú összefüggést a hozamok és a felelös vállalati müködés között (Gillian-Starks, 2017). Fain (2020) vegyes eredményre jut a vállalat pénzügyi teljesítménye és az ESG-pontszám kapcsolatában. Míg a jobb E, S és ESG-minősítés nem befolyásolja szignifikánsan a pénzügyi teljesítményt, addig a vállalatirányítási $(G)$ változó 10 pontos növekedése $0,3 \%$-os javulást eredményez az árbevétel-arányos adózott eredményben.

A bankok, eszközkezelők, nyugdíjalapok és egyéb befektetők az ESG-faktorokat mind kockázatkezelésre (Hoepner et al., 2020), mind befektetési lehetőségek kiaknázására használják (van Duuren et al., 2015). Emellett az országszintű ESGindikátorok alkalmasak lehetnek a szociális ellátórendszer értékelésére illetve az adott ország általános jólétének (well-being) mérésére is (Naffa-Dudás, 2020). Az újdonság és érdekesség az ESG-alapú befektetésekkel kapcsolatban azonban az, hogy pénzügyi döntések születnek nem csupán pénzügyi indikátorok alapján. Ha a befektetői értékítéletben szerepet játszik az ESG-alapú döntés is, akkor ez azt jelenti, hogy a pénzügyi instrumentumok árazását a továbbiakban nem pénzügyi faktorokkal is módosítani kell (Shrivastava et al., 2019).

A kutatásunk során bizonyítást nyert, hogy az ESG-befektetések hatása a részvénypiacokról tovább terjedt a kötvénypiacokra is, eltérően befolyásolva a különböző lejáratú, különböző hitelkockázati kategóriákba tartozó vállalati kötvényárakat. Ez azt jelenti, hogy a hitelezők figyelembe veszik hozamelvárásaik során az adósok ESG-besorolását. Kockázatosabbnak értékelik az olyan vállalatokat, amelyek tevékenységük során kevésbé törődnek a környezetvédelemmel, nem foglalkoznak a társadalmi problémákkal vagy rosszul bánnak az alkalmazottakkal. Ha az ESG-faktorok alapján kockázati prémiumokról beszélhetünk a kötvénypiacon, az azt jelenti, hogy a tulajdonosokon túl (részvényesek) olyan érintett réteg döntésein keresztül is érződik a hozzáadott kockázat, mint a hitelezők (kötvényesek), akik sokkal kevésbé kitettek egy esetleges csődesemény okozta kárnak, hiszen a hitelezők a csődeljárás során a kifizetési hierarchiában előbb helyezkednek el, mint a tulajdonosok. Jelen értekezés eredményei alapján arra következtetünk, hogy az ESG-alapú befektetések árazást érintő hatása annyira erős, hogy a nem közvetlenül a vállalat nyereségében érintett rétegek (stakeholderek) értékítéletét is befolyásolhatja. 
A tanulmány célja az ESG-alapú értékelés fennállásának bizonyítása a vállalati kötvénypiacokon a kötvényárakból felépített hozamgörbék segítségével. Azt vártuk, hogy az alacsonyabb ESG-pontszámú vállalatok által kibocsátott kötvények kockázatosabbak, így a hozamgörbéjük által megtestesített hozamfeláruk nagyobb, mint a magasabb ESG-pontszámmal rendelkező vállalatoké. A jelenséget az amerikai, európai és a japán piacon összességében is megvizsgáltuk, illetve az amerikai piacon tovább szűkítve, egyes hitelkockázati minősítési kategóriákon belül is vártuk a szignifikáns eltérést. Amennyiben egy hitelminősítési kategórián belül is megfigyelhető az alacsonyabb és magasabb ESG-besorolású cégek által kibocsátott kötvények hozamfelárának különbsége, úgy felvetődhet a kérdés, vajon a hitelkockázati besorolás megfelelően méri-e fel a kockázatot pusztán pénzügyi indikátorokra támaszkodva, illetve beszélhetünk-e ESG-kockázatról ez esetben.

\section{ESG ÉS ESG-BEFEKTETÉSEK}

Az ESG egy betűszó, amely az Environmental (környezeti), Social (társadalmi) és Governance (irányítási) szavak rövidítését foglalja magában. A vállalatok belső és külső tevékenysége, a vállalatvezetési gyakorlatok és ezek szabályzatai egyaránt elemezhetők e három pillér vetületében, ami új kapukat nyithat meg a kockázatkezelésben és a tőkepiaci termékek értékelésében.

Míg a környezeti változó a vállalatnak például a hulladékgazdálkodási, károsanyag-kibocsátási, ökológiai lábnyomát méri, addig a társadalmi faktor az adott entitás kapcsolatait sűríti magába a vállalat értintettjeivel (beszállítók, vásárlók, alkalmazottak) és a társadalommal. Idetartozik többek között a munkavédelmi és egészségügyi előírások szabályozása és azok betartása, betartatása is. Végül az irányítási elem a vállalati kultúrát hivatott számszerüsíteni a nemi diverzitástól a felsővezetés bérezésén át egészen a cég adatáramlási irányelveiig (MSCI ESG Ratings, 2020). Az ESG-metrikák gyűjtését, feldolgozását, illetve közzétételét egyre több fintech- és hírszerző cég végzi, mint az MSCI, Sustainalytics vagy a Refinitiv. Az általunk használt, Refinitiv-féle ESG-számokat hetente, illetve ha indokolt, ad hoc frissítik, így mind a szubváltozók, mind maga az összesített ESGbesorolás idővel változhatnak (Refinitiv, 2020).

A portfóliómenedzserek az előző évtizedben kezdtek felelős, fenntartható befektetési stratégiákat használni pénzügyi döntéseik során. Korábban ezek a stratégiák sokszor annyiban merültek ki, hogy akár az eszközkezelő, akár az egyéni befektető kizárt olyan iparágakat a portfóliójából, mint a fegyvergyártás, dohány és alkoholtermeléshez kapcsolódó szektorok. Az utóbbi években viszont jelentős visszhangot kaptak és nagy népszerüségnek örvendenek az olyan alapok, ETF-ek és indexek, amelyeket ESG-faktorok alapján is mérlegelnek. A befektetők ezeket 
a kosarakat a piaci portfóliónál magasabb hozam elérésére és kockázatkezelési célból követik vagy vásárolják, illetve azért, hogy befektetésükkel így egy hosszú távú, fenntartható ügyet támogassanak (MSCI ESG 101, 2020). A fenti folyamatot támasztja alá a US SIF 2016-os jelentése, amely szerint minden ötödik befektetett dollárt már nem pusztán pénzügyi, hanem bizonyos fenntarthatósági szempontot is figyelembe véve fektettek be (US SIF, 2016). Az ESG-alapú befektetések 2013tól mutatnak szignifikáns hatást - főképp az európai és az amerikai tőzsdéken -, például az ESG-faktorok kockázatkezelésben betöltött szerepének a felértékelödésével, illetve a felelős, küldetéstudatos befektetési lehetőségek megfontolásának elöretörésével is. Érdekesség továbbá, hogy nem beszélhetünk egységes trendről a fejlett országok között a felelős befektetésekkel kapcsolatban. Japán és Ausztrália esetében az Európában és Észak-Amerikában megfigyelhető, felfokozott érdeklődés az ESG-alapú befektetések iránt még nem kezdődött el. A jelenséget többek között magyarázhatja a japán vállalati kultúra konzervativizmusa, régimódi volta a nyugati kultúrákhoz képest (Bennani et al., 2018).

\section{ADATKEZELÉS ÉS TISZTÍTÁS}

A kutatás univerzumának a Refinitív vállalati kötvényhozamgörbével támogatott cégeit vettük. A hozamgörbéket a Refinitív köbös spline módszerrel építi fel s interpolálja a megfelelö lejáratokra. A Waggoner, Anderson és Sleath által 2001-ben kidolgozott módszer alapján épített görbék pontosabb előrejelzéseket adtak mind a rugalmasság, mind a stabilitás és simaság tekintetében a többi interpolációs módszerhez képest (Waggoner, 1997; Anderson-Sleath, 2001; Moore, 2017).

Összesen 3100 megfigyelés állt rendelkezésre, ezt a halmazt tovább szürtük az alábbiak szerint:

- Legalább 2015. 01. 05-ig visszamenő hozamidősor

- Legalább 2015. 01. 05-ig visszamenő ESG-idősor

- Legalább 11 meglévő lejárat

- Legalább 5 aktív kötvény

- Legrövidebb kötvény lejárata maximum 3 év

- Van 10 évnél hosszabb lejáratú kötvény

- Az összesített névérték minimum 1 M USD

- Az idősor legalább 80\%-a rendelkezésre áll

A hozamgörbéket az 1 éves és 15 éves lejárat között vizsgáltuk meg. A hosszú véget jellemzően extrapolálással számítják, így a 15 év feletti lejáratokat nem vettük figyelembe. A hozamgörbe különböző pontjai tehát az alábbiak lettek: 1, 2, 3, 4, 5 , 
6, 7, 8, 9, 10, 12 és 15 év. Amennyiben az utolsó lejárat nem volt elérhető, a 12 éveset extrapoláltuk. Az esetlegesen hiányzó adatokat az előző napi megfigyelésekkel töltöttük ki, így 1504 különböző napra kaptunk értékeket.

Az előbbi szűrési feltételeknek megfelelően végül 135 vállalati kötvényhozamgörbét kaptunk az amerikai, 25-öt az európai, illetve 29-et a japán piacon, amelyekhez párosítottuk a kibocsátó hitelkockázati besorolását és az ESG változóit, továbbá az önálló E-, S- és G-faktorokat is. Az egyedi E, S és G változókkal a kisebb, nem pénzügyi mutatókat, mint a környezeti hatást vagy a társadalmi hatást különkülön tudtuk vizsgálni. Ezen görbéket és a szelektált változók kapcsolatát 5,5 éves időtávban, 2015 januárjától 2020 júliusáig minden elérhető napra megvizsgáltuk. A görbéket minden nap sorba rendeztük az ESG-, E-, S- és G-pontszám alapján egyaránt, előbb az adott piacokon, majd az adott piac megfelelő hitelkockázati kategóriáján belül az amerikai vállalatok esetében. Ezt követően az ESG-, E-, S- és G-alapú sorba rendezés után a populációban szereplő hozamgörbéknek a felső és az alsó 10\%-át hasonlítottuk össze, vagyis az ESG-szempontból legjobb és legrosszabb pontszámmal rendelkező vállalkozásoknak a kockázati felárban vett különbségét vizsgáltuk meg. (Amennyiben a részuniverzum túl kicsinek bizonyult, úgy a 10\% helyett 5 megfigyelést alkalmaztunk.) Fontos, hogy mivel kockázati prémiumokat vizsgáltunk, így a hozamgörbék egyes lejárataiból levonásra kerültek a megfelelő devizák kockázatmentes hozamgörbéinek megfelelő pontjai. Amennyiben a kockázatmentes hozamgörbe adott lejárata nem állt rendelkezésre, azt lineáris interpolációval számoltuk.

A 10\% legjobb és legrosszabb ESG-minősítésű vállalat hozamgörbéit az adott piacokon, illetve az amerikai piacon belül adott hitelkockázati besoroláson belül is ábrázoltuk, mind napi keresztmetszeti, mind idősoros adatokon. Fontos kiemelni, hogy az ESG-, E-, S- és G-alapú sorba rendezés az adott populáció vállalatai között napi szinten megtörtént, akárcsak a hitelkockázati besorolás változásának figyelése.

\section{EREDMÉNYEK}

\subsection{Hozamfelár-különbségek napi bontásban}

A korábban bemutatott adatkezelési eljárást alkalmazva a következő eredményeket kaptuk. Mivel az egyes kategóriákban számos hozamgörbét vizsgáltunk, ezek vizualizációja és így az ebből kapott konklúzió nehezen értelmezhető, ezért a 10\% legmagasabb és legalacsonyabb ESG-besorolású vállalat hozamgörbéit átlagoltuk lejáratonként, besúlyozva az egyedi vállalatok kötvényeinek névértékével.

A hozamgörbéket a Moody’s besorolásai alapján három hitelkockázati kategóriába soroltuk. A „Prime 1” csoport a hivatalos Aaa minősítéstől az A1-ig terjed, 
a „Prime 2" az A2 és A3 kategóriát foglalja magában, míg a „Prime 3” a Baa1-et, Baa2-t és a Baa3-at tartalmazza. A Baa3-nál kockázatosabb, spekulatív adósokat tartalmazó kategóriákat nem tudtuk bevonni az elemzésbe, mert a szürési feltételeknek megfelelő hozamgörbék kevesebb mint 10\%-a rendelkezett ilyen hitelminősítéssel, így nem állt rendelkezésünkre megfelelő mennyiségű adat magabiztos konklúzió megalkotására.

\section{1. ábra}

A szürési feltételeknek megfelelő vállalatok hitelminősítési kategóriájának eloszlása (2015. január 5. - 2020. július 31.)

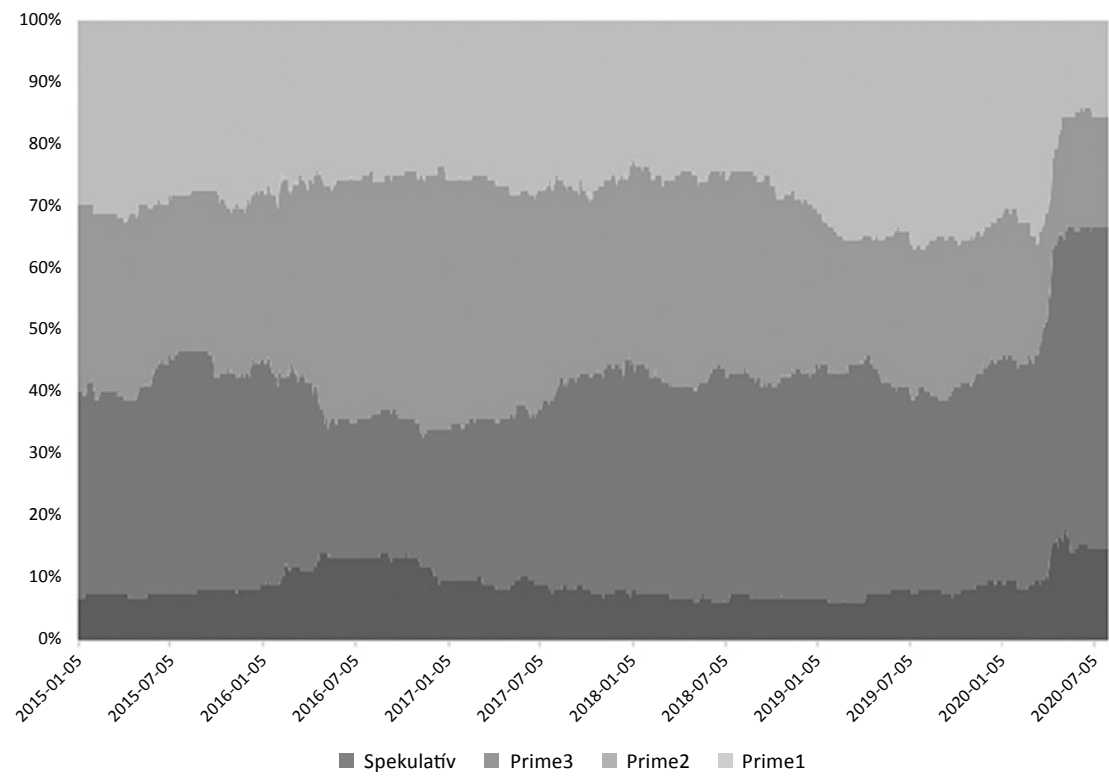

Habár a vizsgált vállalatok hitelminősítése napról napra változik, látható, hogy a Prime 1-3 csoport eloszlása a szürt univerzumon belül nagyjából 30-30-30\%, míg a spekulatív csoport stabilan 10\% körül mozog. 
2. ábra

Az amerikai populáció vállalatai által kibocsátott kötvények hozamgörbéinek ESG-, E-, S- és G-pontszám alapján sorba rendezett, legalacsonyabb és legmagasabb 10\%-a a Moody’s Aaa - A1 hitelkockázati kategóriáin belül (Prime 1), 2020 július 31-én
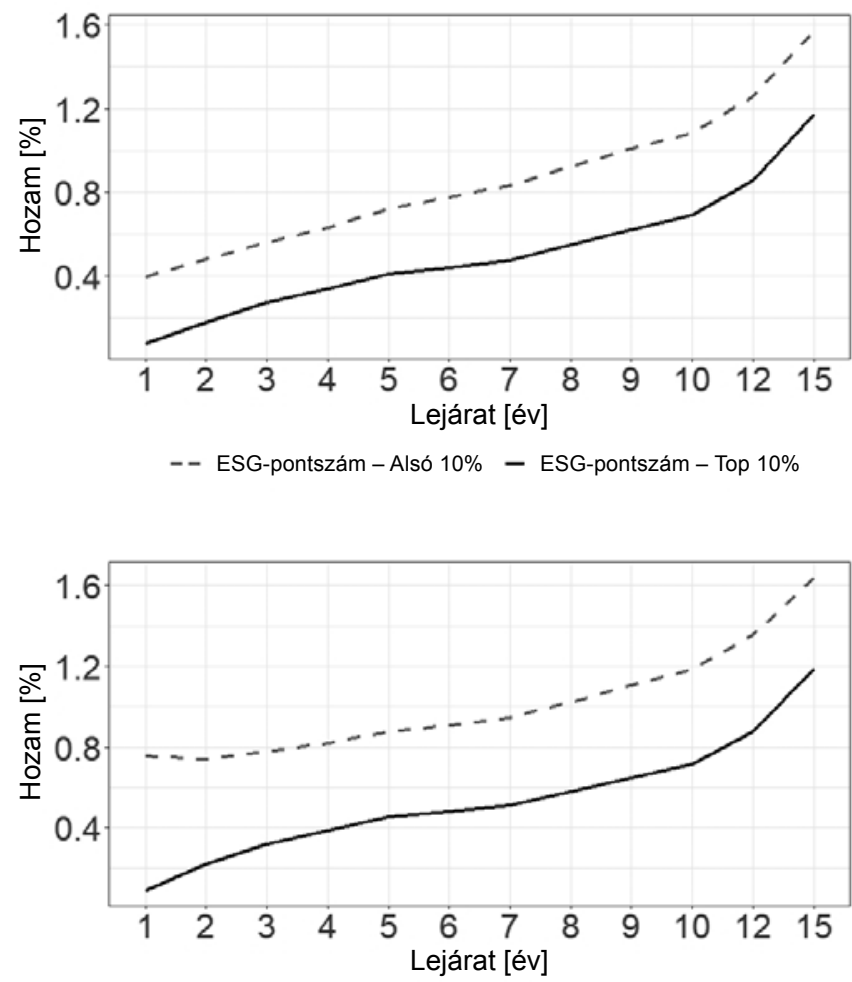

- E-pontszám - Alsó 10\% - E-pontszám - Top 10\%

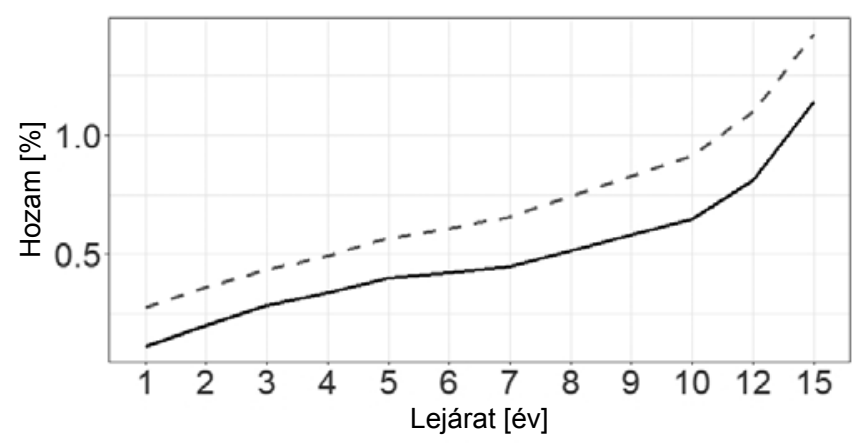

- - S-pontszám - Alsó 10\% - S-pontszám - Top 10\% 


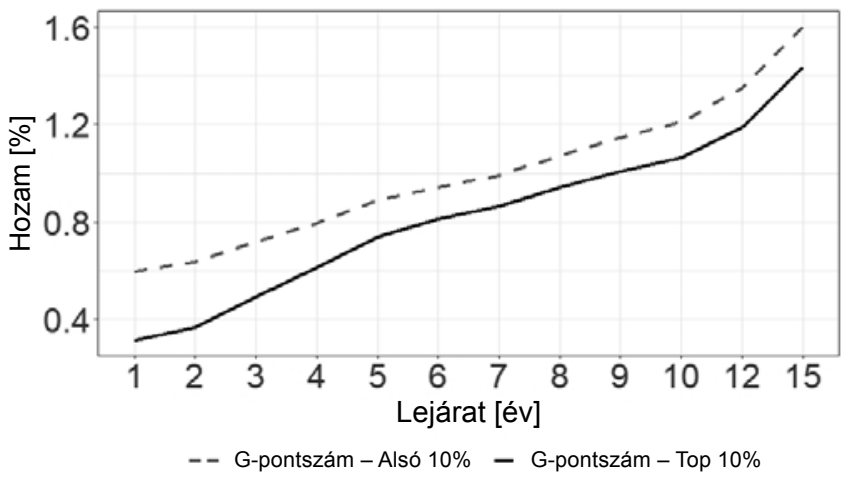

A 2. ábrán látható, hogy 2020 július 31-én az amerikai piacon a leghitelképesebb vállalatok között jelentős különbség volt az ESG alapján legjobban és leggyengébben teljesítő vállalatok által kibocsátott kötvények hozamelvárása között. Ez azt jelenti, hogy a piac kockázatosabbnak értékelte az olyan adósokat, akik rosszabb ESG-besorolással rendelkeztek azonos hitelkockázati kategórián belül. A jelenség mind a környezeti $(\mathrm{E})$, mind a társadalmi (S) és irányítási $(\mathrm{G})$ változók alapján is azonos, azonban a különbség (spread) eltérő.

A hozamgörbék különböző lejáratait is átlagoltuk napi szinten az adott piacokon, illetve az adott hitelkockázati kategóriákban is. A vizsgált időperiódus legutolsó napján a keresztmetszeti adatokat az 1. táblázat tartalmazza. A szigorú szűrési feltételeknek köszönhetően a japán és az európai piacon nem volt megfelelő mennyiségü hozamgörbe ahhoz, hogy a hitelkockázati besorolás tekintetében is magabiztos következtetéseket vonjunk le, így a hitelkockázati dimenziót csak az amerikai piacon tudtuk megvizsgálni.

\section{1. táblázat}

A leszürt univerzum vállalatai által kibocsátott kötvények átlagos hozamfelár-különbségei a hitelkockázati besorolás, illetve a legalacsonyabb és legmagasabb ESG-, E-, S-, G-pontszám tekintetében (2020. július 31.)*

\begin{tabular}{lccccc}
\hline & USA Prime 1 & USA Prime 2 & USA Prime 3 & Európa & Japán \\
\hline ESG & 34,5 & 5,7 & $-39,7$ & $-2,6$ & -19 \\
\hline E & 47,2 & 7,1 & $-32,8$ & 1,5 & $-21,2$ \\
\hline S & 20,8 & $-21,2$ & $-54,5$ & $-9,4$ & $-24,9$ \\
\hline G & 17,6 & -46 & 26,9 & 0,8 & $-1,2$ \\
\hline
\end{tabular}

Megjegyzés: * legalacsonyabb ESG-pontszámú vállalatok hozamfelárainak átlaga - legmagasabb ESG-pontszámú vállalatok hozamfelárainak átlaga (bázispont) 
Az 1. táblázatból további következtetések vonhatók le. 2020. július 31-én az amerikai piacon minél hitelképesebb az adós, annál inkább számít a befektetőknek, hogy az adott vállalat mennyire zöld, mennyire veszi ki a szerepét például a társadalmi felelősségvállalásból, vagy mennyire bánik jól a vállalat közvetett és közvetlen partnereivel, munkavállalóival. Látható, hogy esetenként majdnem 0,5\% hozamprémiumot is elvárnak a befektetők a legjobb adósok körében. Átlagosan 35 bázisponttal magasabb volt a hozamelvárása azon befektetőknek, akik a leghitelképesebb rossz ESG-vel rendelkező adósok kötvényeiből vásároltak, azokkal a kötvényekkel szemben, amelyek szintén ebbe a hitelminősítési kategóriába tartoznak, de ESG-szempontból jobban teljesítenek. Látható, hogy az ESGpontszám okozta hozamfelárat a Prime 1 csoportban leginkább az E környezeti faktor indikálja. Ezen napi adatból levonható az a következtetés, hogy a hitelezők a leginkább a környezeti változóra érzékenyek, a rossz környezeti pontszámmal rendelkező vállalatokat tartják a legkockázatosabbnak. Fontos számukra az irányítási faktor alapján történő besorolás is, ám a társadalmi változóra csupán 16,2 bázispontnyi hozamprémiummal reagálnak.

Megfigyelhető, hogy a rosszabb adósbesorolású vállalatok körében (Prime 2, Prime 3 csoport) az ESG-alapú kockázatfelmérés háttérbe szorult. A Prime 3 csoportban látható, hogy a hitelezők már nem tulajdonítanak hozzáadott kockázatot az ESG-szempontnak, sőt kifejezetten büntetik, ha a kockázatosabb adósok társadalmi és irányítási projektekbe fektetnek ahelyett, hogy elsődlegesen jó adósok legyenek. Következtetésképpen látható, hogy az ESG vezérelte hitelezés leginkább a legjobb adósok privilégiuma, vagyis ha egy vállalat a legszolvensebb kategóriába tartozik, a befektetők akkor várják el igazán, hogy társadalmi és környezeti problémákkal is foglalkozzon, akkor számolnak ESG-kockázattal. Ennél fogva minél gyengébb hitelminősítési kategóriába tartozik az adott vállalat, a befektetők annál kevésbé érzékenyek a felelős működésre. Az E, az S és a G változó jelentősége hozzávetőlegesen 50 bázisponttal csökken hitelminősítési csoportonként.

A keresztmetszeti adatokból ezen a napon Európa és Japán esetében egyértelmü következtetéseket nem tudtunk levonni, így e régiók vizsgálatát az idősoros elemzés tette lehetővé.

\subsection{Hozamfelár-különbségek idősorosan}

A vizsgált időtáv több mint 5 éves, a 2015. január 5. és 2020 július 31. közötti adatokat elemeztük (1504 megfigyelés). A napi hozamfelárak egyes lejáratait átlagoltuk, így az egy görbéhez tartozó kockázati prémiumokat egyetlen adatpontba sürítettük. Míg a portfólió statikus, vagyis ugyanazon vállalatok által kibocsátott kötvények hozamfelárait tartalmazza naponta, addig az egyes görbék ESG- és hitelminősítési besorolása és szelektálása dinamikus, azaz minden nap részport- 
fóliókat alakítottunk ki aszerint, hogy az adott vállalat a vizsgált napon milyen ESG-pontszámmal és hitelminősítéssel rendelkezett (hiszen ezek a pontszámok akár napról napra változhatnak).

\section{3. ábra}

Az amerikai populáció vállalatai által kibocsátott kötvények hozamgörbéi súlyozott átlagának az ESG-, E-, S- és G-pontszám alapján sorba rendezett, legalacsonyabb és legmagasabb 10\%-a a Moody's Aaa - A1 (Prime 1)

hitelkockázati kategóriáin belül (2015 január 5. - 2020. július 31.)
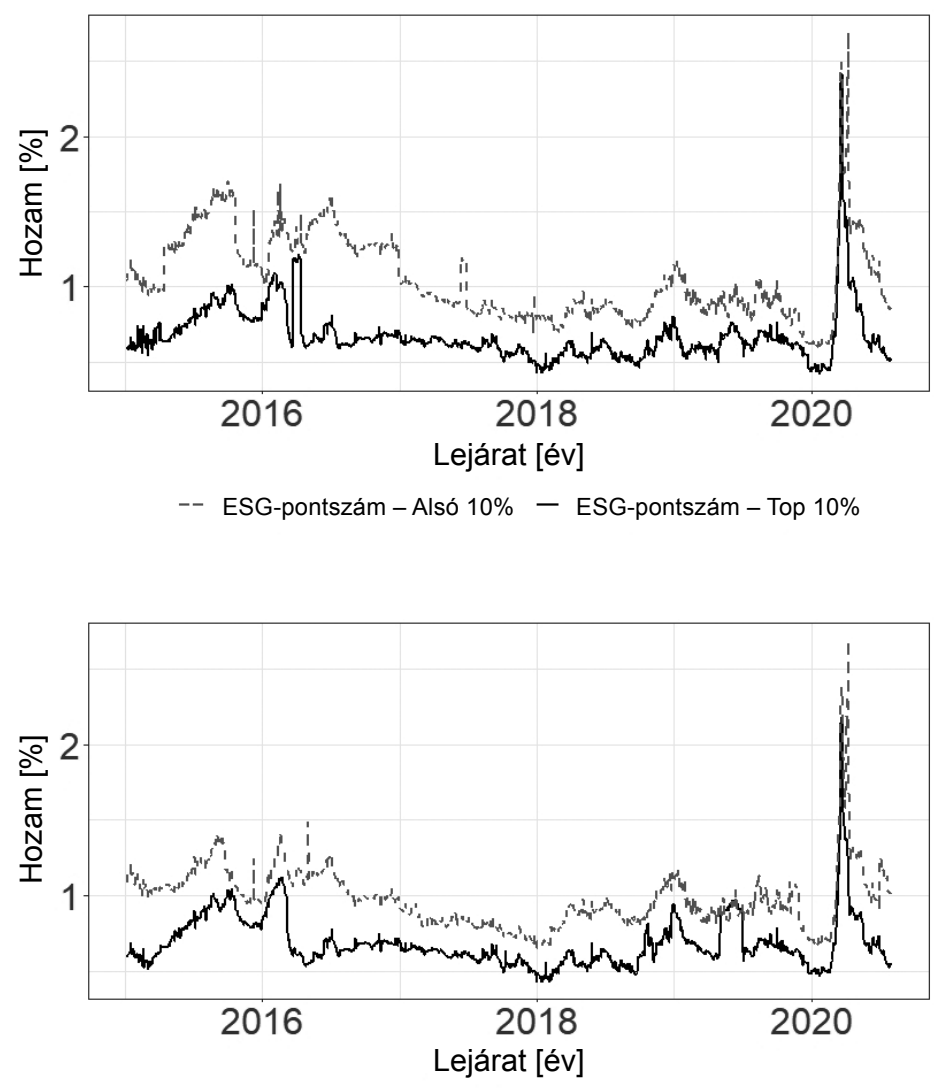

-- E-pontszám - Alsó 10\% - E-pontszám - Top 10\% 


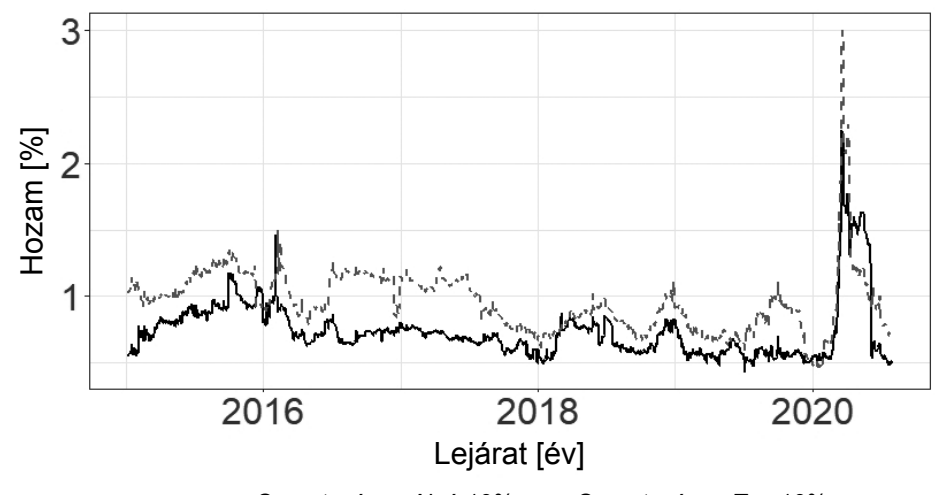

-- S-pontszám - Alsó 10\% - S-pontszám - Top 10\%

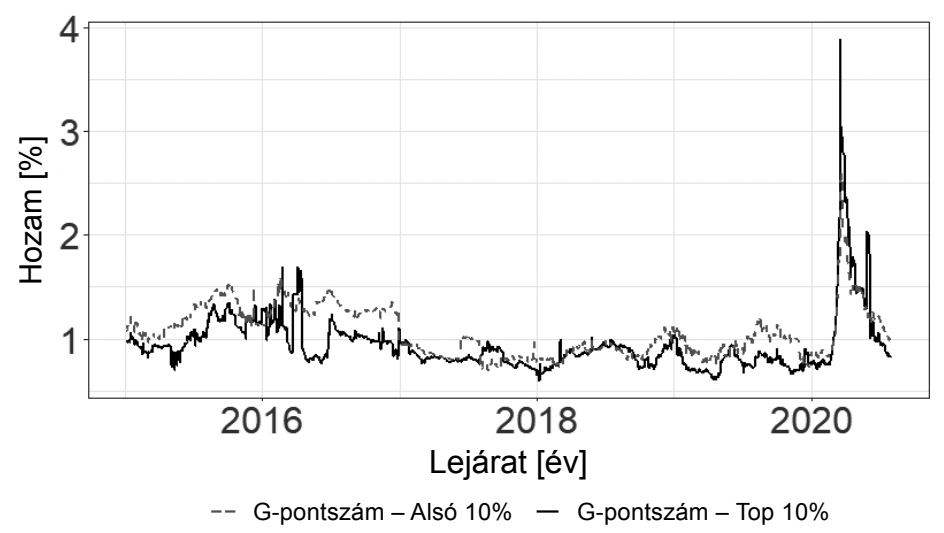

A vizsgálat robusztusságának köszönhetően jól látható a Prime 1 csoporton belül, hogy az idősoros elemzés egybecseng az utolsó megfigyelés napján kapott keresztmetszeti eredményekkel. Stabil hozamfelár-különbség figyelhető meg mind az ESG, E, S és G mentén szétválasztott vállalati kötvények hozamfelárai között. Ugyanúgy, mint a napi bontásnál, elmondható, hogy az ESG-összpontszám, illetve a környezeti (E) pontszám okozza a legjelentősebb kockázati prémiumban mérhetö különbséget az amerikai piacon. Ezen különbség 5 éven keresztül megfigyelhető, azonban érdemes kitérni a koronavírus-járvány (Covid-19) kirobbanásakor megfigyelhető trendre is. Látható, hogy az alacsony és a magas ESG-pontszámú cégek hozamfelárai közötti különbség eltűnik, vagyis a hitelezők válsághelyzetben eltekintenek attól, hogy az adott vállalat mennyire felelösen müködik, egyformán kockázatosnak ítélik az adott hitelkockázati kategórián belüli kötvényeket. A pánik enyhülésével azonban a trend ismét megfigyelhetően visszaáll a járvány előtti állapotra, $s$ a hozamfelárak ismét jelentősen szétválnak. 


\section{4. ábra}

A japán populáció vállalatai által kibocsátott kötvények hozamgörbéi súlyozott átlagának az ESG-pontszám alapján sorba rendezett, legalacsonyabb és legmagasabb 10\%-a (2015. január 5. - 2020. július 31.)

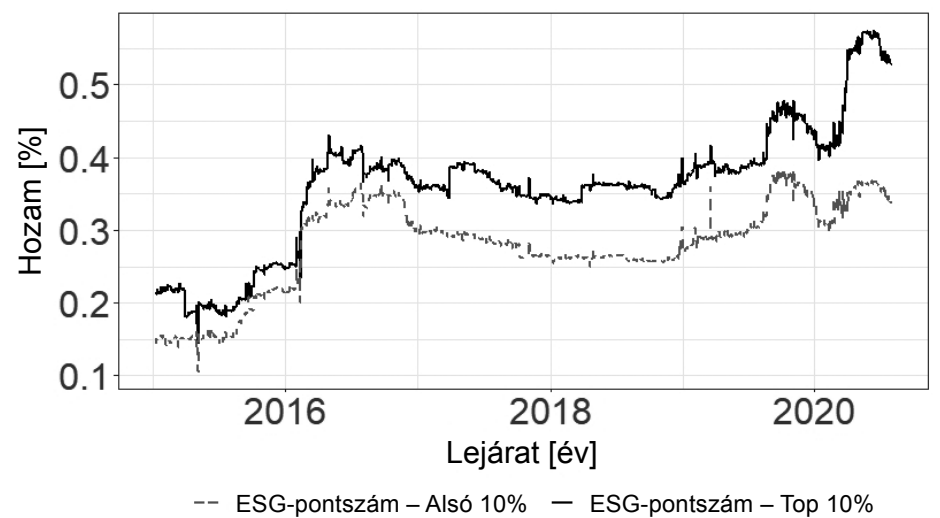

5. ábra

Az európai populáció vállalatai által kibocsátott kötvények hozamgörbéi súlyozott átlagának az ESG-pontszám alapján sorba rendezett, legalacsonyabb és legmagasabb 10\%-a (2015. január 5. - 2020. július 31.)

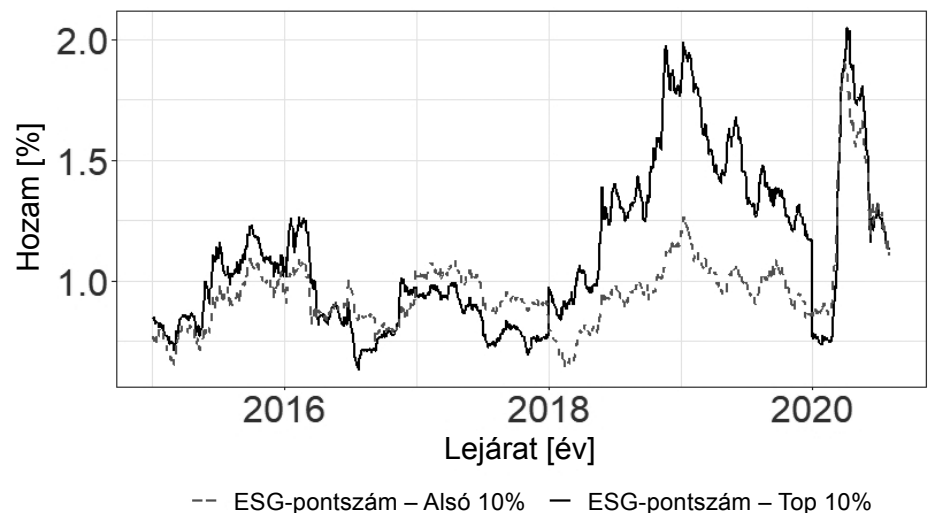

Az európai, illetve a japán kötvénypiacon egymástól és az amerikai piactól is eltérő trend figyelhető meg. Míg a japán piacon stagnálóan a legjobb ESG-pontszámmal rendelkező vállalatok által kibocsátott kötvények hozamfelára magasabb, mint az alacsonyabb ESG-pontszámú vállalatoké, addig az európai piacon e trend vál- 
takozó, egyes periódusokban az alacsonyabb, másik időszakokban a magasabb ESG-pontszám jelent hozzáadott kockázatot. E trendek mindkét piacon megfigyelhetők az E-, S- és G-faktorokra egyaránt. Az eredmények értelmében levonható a következtetés, hogy a japán - csakúgy, mint az ázsiai - piacok még nem jutalmazzák a felelős vállalatokat, sőt kockázatosabbnak tartják azokat a cégeket, amelyek környezeti, társadalmi vagy irányítási projekteken is dolgoznak ahelyett, hogy pusztán financiális és jövedelmezőségi irányokat tartanának szem előtt.

Az európai piacon váltakozó trend figyelhető meg a kötvényfelárak és az ESGpontszámok tekintetében. Egyes periódusokban a magas ESG-pontszám jelent hozzáadott kockázatot, más időszakokban pedig ennek az ellenkezője történik, a felelös vállalatvezetést kevésbé kockázatosnak ítélik a hitelezők. További kutatást igényel annak a megismerése, vajon milyen események hatására jelentek meg a fordulópontok az európai piac esetében. Gazdasági visszaeséskor azonban, mint a 2019-es Covid-19-járvány, hasonló trend figyelhető meg, mint az amerikai piacon. A nem pénzügyi kockázatmérséklés háttérbe szorul, s mind az ESGszempontból jól, mind a rosszul teljesítőket egyformán kockázatosnak értékelték.

A kapott idősoros eredmények egybecsengenek több korábbi, részvénypiacokon végzett kutatás eredményével (pl. Bennani et al., 2018). Míg a felelös vállalatvezetés először az amerikai részvénypiacon okozott a benchmarkhoz képest hozzáadott hozamot, majd később gyürüzött át az európai piacokra, s még mindig nincs vagy nagyon alacsony hatása van az ázsiai piacokra, addig a kötvénypiacokon egy késleltetett folyamat figyelhetö meg, ahol az ESG okozta kockázatmérséklés az amerikai piacokon már jelen van, az európai piacokon egy átmenet figyelhető meg, s a japán piacot még nem érte el, sőt, kockázatosnak ítélik a hitelezők.

\section{6. ÖSSZEGZÉS}

A kutatás eredményeire hivatkozva, a vizsgálat robusztusságának köszönhetően levonhatjuk a következtetést, hogy nem pusztán pénzügyi megfontolások számítanak az adós kockázatának felmérése során az USA-ban. E trend már megfigyelhető volt a részvénypiacok esetében, azonban a kötvénypiacokon ez azt jelenti, hogy a hitelezők várakozásaiba is beépül az ESG-kockázat. Egy olyan érintetti kör várakozásairól beszélünk (hitelezők), akik sokkal kevésbé kitettek egy esetleges csőd során elszenvedett kárnak, hiszen a hitelezőket mindig előbb fizetik ki, mint a tulajdonosokat.

Azonos hitelminősítési kategórián belül, pénzügyileg azonos hitelképességü vállalatok körében az ESG-pontszám elkülönítő tényező az Egyesült Âllamokban. Az utóbbi 5 évben az amerikai piacon azokat a vállalatokat kockázatosabbnak ítélte a piac, amelyeknek az ESG-pontszáma alacsonyabb volt, azaz környezeti, 
társadalmi vagy vállalatvezetési szempontból kevésbé felelősen müködtek. E hatás nemcsak az összesített pontszámnál (ESG) jelentkezett, hanem a faktoroknál külön-külön is. További trend, hogy minél jobb az adósbesorolása egy vállalatnak, annál inkább számít a hitelezőknek a felelős müködés, a rosszabb hitelminősítési kategóriákban inkább hátrányosnak ítélik meg, ha egy vállalkozás a fizetőképesség mellett a felelős működésre fókuszál. Az európai piacon e trend váltakozó, az ázsiai (japán) piacokon pedig e trend még ellentétes: negatívan értékelik a nem pusztán pénzügyi szempontokat figyelembe vevő vállalatvezetést.

A fenti kutatás számos további kvantitatív és kvalitatív kérdést felvet. Többek között, hogy vannak-e olyan események, amelyek katalizálják az európai piacon a váltakozó trendet, vagy hogy mi húzódik meg a háttérben a japán piacon megfigyelhető trend mögött.

\section{HIVATKOZÁSOK}

Amel-Zadeh, Amir - Serafeim, George (2017): Why and How Investors Use ESG Information: Evidence from a Global Survey. Financial Analysts Journal 74(3), 87-103., DOI: http://dx.doi. org/10.2139/ssrn.2925310.

Anderson, Nicole - Sleath, John (2001): New estimates of the UK real and nominal yield curves. Bank of England Working Paper Series, https:/www.bankofengland.co.uk/-/media/boe/files/ working-paper/2001/new-estimates-of-the-uk-real-and-nominal-yield-curves.pdf?la=en\&hash

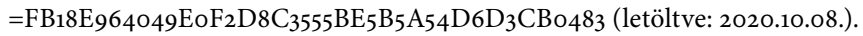

Bennani, Leila - Le Guenedal, Théo - Lepetit, Frederic - Ly, Lai - Mortier, Vincent Roncalli, Thierry - Sekine, Takaya (2018): How ESG Investing Has Impacted the Asset Pricing in the Equity Market. DOI: http://dx.doi.org/10.2139/ssrn.3316862.

van Duuren, Emiel - Plantinga, Auke -Scholtens, Bert (2016): ESG Integration and the Investment Management Process: Fundamental Investing Reinvented. Journal of Business Ethics 138, 525-533., DOI: https://doi.org/10.1007/s10551-015-2610-8.

FAIN MÁTÉ (2020): A vállalati társadalmi teljesítmény rövid távú hatásai a pénzügyi jövedelmezőségre. Köz-Gazdaság - Review of Economic Theory and Policy 15(2), 163-179.

Friede, Gunnar - Busch, Timo- Bassen, Alexander (2015): ESG and financial performance: aggregated evidence from more than 2000 empirical studies. Journal of Sustainable Finance of Investment 5(4), 210-233., DOI: 10.1080/20430795.2015.1118917.

Gillan, Stuart L. - Starks, Laura T. (2007): The Evolution of Shareholder Activism in the United States. Journal of Corporate Finance 19(1), 55-73. DOI: https://doi.org/10.1111/j.17456622.2007.00125.x.

Hoepner, Andreas - Oikonomou, Ioannis - Sautner, Zacharias - Starks, Laura T. - Zhou, Xiaovan (2019): ESG Shareholder Engagement and Downside Risk. European Corporate Governance Institute - Finance Working Paper No. 671/2020. DOI: http://dx.doi.org/10.2139/ ssrn.2874252.

MSCI (2020): ESG 101: What is ESG? (https://www.msci.com/what-is-esg, letöltve: 2020.10.08.).

MSCI (2020): ESG Ratings (https://www.msci.com/esg-ratings, letöltve: 2020.10.08.). 
NAfFa Helena - DudÁs FANNI (2020): Milyen szerepet töltenek be az országszintű ESG-indikátorok, valamint a globális pénzügyi inklúziós indikátorok a szociális és pénzügyi jólét meghatározásában? Köz-Gazdaság - Review of Economic Theory and Policy 15(2), 156-162.

Orlitzky, Marc - Schmidt, Frank L. - Rynes, Sara L. (2003): Corporate Social and Financial Performance: A Meta-Analysis. Organizational Studies 24(3), 403-441. DOI: https://doi.org/10. 1177/0170840603024003910.

Refinitiv (2020): Environmental, Social, Governance (ESG) Scores from Refinitiv (https:// www.refinitiv.com/content/dam/marketing/en_us/documents/methodology/esg-scoresmethodology.pdf, letöltve: 2020.10.08.).

Reuters (2017): Thomson Reuters Credit Curve Methodology. (https://www.aer.gov.au/system/files/ ACCC $\% 20-\% 20$ Thomson\%2oreuters\%2ocredit\%2ocurve\%2omethodology\%2O-\%20Note\%2O for\%2othe\%20AER\%20-\%20April\%202017_1.pdf, letöltve: 2020.10.08.)

Shrivastava, Paul - Zsolnai, Laszlo - Wasieleski, David -Stafford-Smith, Mark -WalKer, Thomas -Weber, Olaf -Krosinsky, Cary - Oram, David (2019): Finance and Management for the Anthropocene. Organization \& Environment 32(1), 26-40. DOI: https://doi. org/10.1177/1086026619831451.

US SIF (2016): Report on US Sustainable, Responsible and Impact Investing Trends 2016 (https://bit. ly/2HriyFp, letöltve: 2020.10.08..

Waggoner, Daniel F. (1998): Spline Methods for Extracting Interest Rate Curves from Coupon Bond Prices. Federal Reserve Bank of Atlanta Working Paper 97-10. DOI: http://dx.doi. org/10.2139/ssrn. 86789 . 